\title{
STUDIES IN MYSTICISM AND MYSTICAL EXPERIENCE IN SOVIET AND POST-SOVIET RUSSIA
}

\author{
TATIANA MALEVICH \\ Russian Academy of Sciences
}

\begin{abstract}
The paper highlights the key perspectives on mysticism typical for Soviet and Post-Soviet religious studies. Recognizing the vagueness of the 'mystical', Soviet scholars interpreted it as a belief in 'communication' with 'supernatural powers'. Furthermore, 'mysticism' was thought of as a multicomponent entity composed of (1) mystical experiences, (2) mystical beliefs, and (3) 'mysticism' as a 'false ideology'. Such an understanding resulted from their epistemological settings, i.e. the reflection theory of dialectical materialism. In this light, mystical experiences and beliefs were distorted 'reflections' of objective reality in the human mind caused by factors both of an individual and a social nature. This understanding still defines the academic interpretations of the 'mystical' in Russia today.
\end{abstract}

Mysticism and related phenomena were far from being the centrepiece of religious studies in the Soviet Union. However, beginning in the late 1950s they became a matter of keen and persistent, though not universal, interest for scholars of religion in the Soviet Union, ${ }^{1}$ who developed an understanding of them as part of their Marxian approach to the study of religion. This understanding seems to continue to shape the interpretations of the 'mystical' in religious studies in Russia today. ${ }^{2}$

\footnotetext{
${ }^{1}$ For an overview of the works directly or indirectly devoted to the study of mysticism and mystical experience published in the Soviet Union, see I. V. Devina's article, 'Mysticism and Religion' (Devina 1989).

${ }^{2}$ It should be noted that this article deals with general theoretical interpretations of mysticism and related phenomena elaborated in the Soviet Union, and with the influence of those interpretations on the contemporary understanding of mysticism and mystical experience in Russian religious studies, rather than with an analysis of particular trends within different mystical and religious traditions. For this reason, many prominent
} 
In general, the specific nature of this understanding, as contrasted with the understanding of this field of research in the West, is evident in the following (undoubtedly interrelated) points. First, there were no intense discussions concerning the methodological and epistemological problems of studying mysticism and mystical experience in Soviet religious studies. Second, there was a shift from the empirical side of mysticism to its sociocultural and epistemological aspects. Third, discussion of the 'mystical' was transferred from the field of psychology of religion to the field of philosophy of religion. Fourth, there was an extremely broad interpretation of the category of 'mystical'. This last point will be the starting point for our analysis.

\section{THE DEFINITION OF THE 'MYSTICAL' AND ITS STRUCTURE}

Recognizing the vagueness of the concept 'mystical' and related concepts such as 'mystical experiences', 'mystical consciousness', and 'mysticism,' ${ }^{3}$ Soviet scholars of religion developed their own relatively homogeneous interpretation of these concepts, suggesting that the key feature of the 'mystical' was a so-called 'duplication of reality'. By this, they meant a belief in the existence of some 'supernatural powers' and a belief that one could 'communicate' or have a 'direct contact' with such powers (for example, cf. Gurevich 1989: 229; Shakhnovich 1965: 3;

works, which tend to be categorized under the topic of 'mysticism' in Russian academic literature, are omitted from this article, such as those on the mystical dimension of Christianity (especially in the area of the Rhenish mysticism; e.g. Khor'kov 2003; Reutin 2011), Islam (e.g. Stepanyants 2009; Nasyrov 2006), Buddhism and Hinduism (e.g. Abaev 1983; Shokhin 1994), Taoism (e.g. Torchinov 1993), etc., as well as works related to various aspects of new religious movements and heretical movements in Orthodox Christianity (e.g. Balagushkin 1989; Panchenko 2004), esoteric traditions, and Freemasonry (e.g., Pakhomov 2013; Khalturin 2013). It is also worth noting here that all these areas have been actively discussed in recent years at the conferences conducted by the Association for the Study of Esotericism and Mysticism (ASEM) (see, for example, some of their published materials: Pakhomov 2009; 2010; 2011; 2012); nevertheless, it should be recognized that even there general theoretical issues concerning the phenomena of mysticism and mystical experience as such (in contrast with those concerning the phenomena of esotericism and occultism) have rarely become central to the discussion.

${ }^{3}$ Statements recognizing the vagueness of these concepts were usually accompanied by references to Ludwig Feuerbach with some variation of the following claim: 'It was Feuerbach who rightly complained about there being too much vagueness in that expression' (Plekhanov 1977: 128; cf. Shakhnovich 1965: 4; Eremenko 1978: 11-15; Khrshanovsky 1977: 15). 
Shakhnovich 1970: 7; Khrshanovsky 1977: 23; Mitrokhin 1989: 3-5; Grigorenko 1986: 8; Ugrinovich 1986: 153). At the same time, one of the classical definitions of mysticism, from the Russian ethnographer Alexander Pypin (1833-1904), was made 'official' by the Russian Marxist philosopher Georgi Plekhanov (1856-1918) in his essay 'Mysticism and Freemasonry in the West and in Russia' (1915-16) (Plekhanov 1977: 128; cf. Shakhnovich 1965: 3). I shall quote it in full: 'In general, the term "mysticism" is applicable to the moral and religious views assuming that a clear idea of the deity, nature, and humanity cannot be grasped by means of ordinary human cognition, nor is it given at any positive religion, and that there is no way to achieve it but a direct approach to the deity, a wonderful union with the supreme divine world, which takes place beyond all dry reasoning.' (Pypin 1916: 204)

This broad understanding of mysticism was partly due to the confusion of different concepts such as: (1) 'religious mysticism'; (2) 'mysticism' and 'mystical' in their popular sense, which comprised anything regarded as 'secret', 'occult,' 'supernatural', or 'mysterious'; and (3) 'mystic' in the Lévy-Bruhlean sense, which implies a 'belief in forces and influences and actions which, though imperceptible to sense, are nevertheless real' (this confusion persisted despite the distinction made by the French anthropologist himself; cf. Lévy-Bruhl 1923: 7). Accordingly, these concepts required further classification. ${ }^{4}$ Such a classification was provided, for example, with the introduction of the categories of 'church' mysticism and 'churchless' or 'nonconfessional' mysticism. The latter comprises a number of heterogeneous, 'non-traditional religious' phenomena, including anything from theosophy, occultism, spiritualism, alchemy, Gnosticism, Hermeticism, mantics, and astrology, to so-called 'extrasensory perception', entheogenic experiences, 'rock

${ }^{4}$ Of course, a broad understanding of the 'mystical' is found not only in Soviet religious studies, but also, for example, in William James' classic 'Varieties', where he says that "the words "mysticism" and "mystical" are often used as terms of mere reproach, to throw at any opinion which we regard as vague and vast and sentimental, and without a base in either facts or logic'; moreover, 'for some writers a "mystic" is any person who believes in thought-transference, or spirit-return' (James 2008: 277). However, whereas there has been a general tendency within research on mysticism and mystical experience in the West to narrow down these concepts, especially through 'purifying' them from allegedly 'secondary' or 'unusual' phenomena (with the notable exception of the approach proposed by J. B. Hollenback, who considers the phenomena that 'accompany' mystical experiences as their essential component; cf. Hollenback 1996: viii), Soviet religious studies moved in the opposite direction. 
festivals', etc. (e.g., Shakhnovich 1965; Gurevich 1989; Polikarpov 1990; Vasil'ev 1963). The most authoritative classification of nonconfessional mysticism may be the one proposed by Soviet scholar of religion Mikhail Shakhnovich (1911-1992). He understood the members of this category to be defined by the following characteristics: 1) 'a tendency to ascribe a supernatural origin to "mysterious" natural and social phenomena'; 2) interpretations of 'scientific "discoveries" as evidence in favour of mysterious, unknowable forces'; 3) 'religious teachings' that go beyond any particular religion (e.g., theosophy and anthroposophy); 4) so-called 'primitive residual beliefs in spirits or in magical impersonal forces' (e.g., spiritualism and occultism); 5) domestic magic (Shakhnovich 1965: 4; cf. Khrshanovsky 1977: 23-24; Eremenko 1978: 9, 22, 35-39; Grigorenko 1986: 8-13). Often, religious and social phenomena such as 'Zen', 'Yoga', 'Satanism,' 'the hippie movement', 'parapsychology', etc., were categorized in a special subgroup under the term 'neomysticism' (for example, cf. Eremenko 1978: 35-39).

Religious studies in modern Russia have generally inherited this broad understanding of mysticism as a faith in 'supernatural powers' and an ability to communicate with them, as well as the subsequent classification of types of mysticism. In particular, there is a division of mysticism into two ('church' and 'churchless' or 'nonconfessional') or even three ('orthodox', 'heretical', and 'nonconfessional') types. ${ }^{5}$ As a consequence, we can now find a variety of things within the realm of the 'mystical': magic, occultism, alchemy, ufology, astrology, spiritualism, fantasy fiction, witchcraft, healing, entheogenic experiences, etc.; the Harry Potter series and the writings of J. R. R. Tolkien and H. P. Lovecraft are all regarded as mystical; a mystical character is ascribed to the Goth and Rastafarian subcultures; and Teresa of Avila, the 'community of hermits in the village of Poganovka and in Kazan awaiting the Doomsday', Aleister Crowley, spiritualists, and shamans, are all labelled as 'mystics' (for example, cf. Balagushkin 2008: 29-34, 42-47; Yatskevich

${ }^{5}$ An 'orthodox' type of mysticism comprises a number of mystical teachings and practices related to traditional religiousness, and is often reduced to the church-related forms of religiousness in Christianity. A 'heretical' type includes a variety of mystical teachings and practices in an extreme form, such as excessively ascetic practices; these forms are in opposition to established religions, again, especially to Christianity). A 'nonconfessional' type refers to a wide range of phenomena, from theosophy and anthroposophy to spiritualism, occultism, and magic (for example, cf. Yablokov 2002: 411). 
2004: 12-13, 25-26, 42; Klimovich 2003: 7; Romanova 2008: 197; Volkova 2002: 4; Tazhurizina 2006: 642; Shakhmatova 2000: 47-75). ${ }^{6}$

Another characteristic feature of research concerning mysticism in Soviet Russia was (and, in post-Soviet Russia, still seems to be) the tendency to identify senses of 'mysticism'. Soviet religious scholars have interpreted 'mysticism' (mistika in Russian) ${ }^{7}$ as having the following three senses: (1) mystical experiences, which can be examined from the radical 'medical materialist' (cf. James 2008: 11-27) standpoint, and are considered to be a psychophysiological substrate underlying mysticism in the broad sense of the word; (2) 'mysticism' (mistika) in the strict sense of the word as a mystical 'attitude' or 'world perception', i.e., the belief in the possibility of 'direct contact' with the 'supernatural' realized (according to the mystics) in mystical experience; and (3) 'mysticism' (mistizism) as the rationalization of the first two elements in a kind of mystical 'ideology', i.e., a set of mystical teachings, and philosophical and theological systems constructed on the basis of these teachings (for example, cf. Rozhnov 1977: 7; Khrshanovsky 1977: 16; Mitrokhin 1989: 3-5).

The tendency to draw a distinction between the notions of 'mysticism' as mistika and 'mysticism' as ideology, which has made quite an impact on the current state of research in the field, ${ }^{8}$ might date as far back as the interpretations of these terms in Russian religious philosophy. To illustrate, Vladimir Solovyov (1853-1900), a famous Russian philosopher, meant by 'mysticism' as mistika a 'direct and immediate relation of our

${ }^{6}$ In this context, the approach developed by an eminent Russian buddhologist and scholar of religion, E. A. Torchinov (1956-2003), which emphasized the vagueness of the word 'mysticism' and related terms, and proposed replacing them with the term 'transpersonal experiences', stands out (cf. Torchinov 2005: 31-34).

${ }^{7}$ It should be noted that there is a distinction in Russian that is quite difficult to translate into English. The Russian word mistika has at least two meanings: the first, which is the popular meaning, applies to anything mysterious and strange (in this regard, it could be compared to the English word 'mystique'); the second designates mysticism (mistizism) in the proper sense of the word. Some scholars consider the terms mistika and mistizism to be synonymous, whereas others tend to focus on their distinction.

${ }^{8}$ For example, Russian scholar of religion Evgenii Balagushkin defines 'mysticism' (mistizism) as 'belief in a direct relation of things to the Sacred Source, sometimes systematically represented in the form of rationalistic theological doctrines of ideological and worldview character', whereas 'mysticism' as mistika is any kind of 'spiritual and practical activities based on such beliefs and undertaken by the adept in order to fulfill that direct relation of things to the Sacred Source' (Balagushkin 2008: 36; cf. Abdurashidova 2010: 131; Bessonova 1998: 38-39; Volkova 2002: 18-19; Volkov 2004: 20-21). 
spirit to the transcendent world', whereas he regarded 'mysticism' as such to be 'a reflection of our mind on that relation' constituting 'a special direction in philosophy' (Solovyov 1988: 152). However, it should be recognized that such a dichotomy was not peculiar to Russian authors. Similar attempts were made, for instance, by the English scholar William Ralph Inge (also known as Dean Inge) who strongly suggested attributing to these concepts different meanings based on the German distinction between die Mystik as 'a genuine type of religion', and der Mystizismus as its 'perversions' (Inge 1947: 25; cf. Inge 1918: 344). In Germany, Friedrich Schleiermacher held that 'there is a great, powerful mysticism (Mystik)', but warned against 'any effort to penetrate into the nature and substance of things', which could lead to falling into 'mysticism (Mystizismus) and empty mythology' (Schleiermacher 1821: 83, 228); moreover, in the preface to the third edition of his 'Speeches on Religion' (1821) he rejected the charges of 'Spinozism and Herrnhutianism, atheism and mysticism (Mystizismus)' levelled against him (Schleiermacher 1821: xvi).

\section{MYSTICISM AS AN IDEOLOGY: THE 'SCIENTIFICATION' OF MYSTICAL TEACHINGS}

By 'mysticism' as mistika Soviet scholars of religion often meant 'a practical kind of religion', aimed at the realization of so-called 'direct contact with supernatural powers' (i.e. what is usually known as 'mystical experience' and 'mystical practices'), while 'mysticism' as mistizism was regarded as its rationalization, a 'surrogate' for science, or a kind of 'mystical' ideology indicating the 'spiritual decline and decay of society' (Shakhnovich 1965: 15; cf. Khrshanovsky 1977: 16; Grigorenko 1986: 133-145). ${ }^{9}$

Mysticism as mistizism, according to Soviet scholars of religion, differed from religion itself. The former, unlike the latter, was not limited to faith, but claimed to be a kind of scientific (or rather pseudoscientific) knowledge: it was alleged that mystics strove to unravel the 'mysteries

${ }^{9}$ Interestingly, while there was (and still is) a tendency in Western psychology of religion and sociology of religion to distinguish between the concepts of 'spirituality' and 'religion', and to identify 'mystical experiences' with 'spiritual experiences' or at least relate them to the field of spirituality (for example, cf. Krishan 1954; Zinnbauer et al. 1997; Hood 2006), religious studies in the Soviet Union set 'mysticism' and 'mystical' against the 'spiritual', labelling mysticism as something 'non-spiritual' or even 'antispiritual' (e.g. Rotovsky 1989; Shakhnovich 1965). 
of the Universe' and to control others with their power. ${ }^{10}$ Mysticism (mistizism) was regarded to be opposed to materialism because it was held to be 'a manifestation of religious and idealistic ideology' that relied on intuition as its own 'scientific method. Furthermore, it was regarded to be a result of the 'scientification' of mystical beliefs (mistika), which had many similarities to the 'bourgeois', 'mystified' science of the $20^{\text {th }}$ century, in particular, to Paul Feyerabend's epistemological anarchism (for example, cf. Shakhnovich 1965: 3-7; Shakhnovich 1970: 7; Gurevich 1984: 155-160, 194-210). ${ }^{11}$

We should mention once again that this tendency to invest mysticism with ideological characteristics was not peculiar to the Soviet Union. Whereas in the Soviet scientific literature mysticism became an 'ideological target' and a very convenient object of criticism, ${ }^{12}$ in the West it was suggested that mysticism should be used as 'an important weapon in the struggle against Communism' - at least, such a suggestion was made in 1964 by Walter Huston Clark in his Presidential Address to the Society for the Scientific Study of Religion (cf. Clark 1965: 160161). Nevertheless, Clark's ambition to invest mysticism and mystical experience with anti-communist qualities did not enjoy the support of his colleagues because of the ideology-neutral nature of mysticism and related phenomena. Furthermore, his colleagues pointed out the erroneous juxtaposition of religion and communism, since the latter might itself be seen as a form of quasi-religion (e.g., cf. Angeles 1966: 292-293).

The understanding of mysticism as a false ideology resulted from the epistemological settings of Soviet scholars. It should be recalled that, in the Soviet Union, the theory of knowledge of dialectical materialism, with Lenin's reflection theory at its core, served as the 'methodological

${ }^{10}$ Here, the interpretation of 'mysticism' sounds more like Bronisław Malinowski's understanding of 'magic' as a sort of 'pseudo-science'.

11 This tradition of equating religious mysticism and mystical experiences with various forms of philosophical irrationalism still remains, though now without negative connotations (for example, cf. Tolstikov 2007: 42).

${ }^{12}$ It is worth considering the number of scientific and popular books, tracts, and articles published in the USSR in order to expose the 'reactionary nature' of 'mystical ideology'. Their titles speak for themselves: 'Mysticism and Occultism in the Service of the "Neoconservative Wave" ideologues', (Kononov 1985); 'Mysticism in the Service of Anti-Communism', (Belov and Karpov 1978); 'Neomysticism and the Difficulties of Ideological Warfare', (Rotovsky 1989); 'Mysticism in the Service of Modern Orthodoxy', (Gordienko 1981), etc. 
and theoretical basis of all scientific knowledge' (Podosetnik 1969: 173). In general, the reflection theory holds that: (1) the object of cognition, i.e., the external world, exists independently of human consciousness; (2) cognition is an active, creative process, which includes the 'union of cognition and practice'; (3) the results of cognitive activity are adequate to the content of the object of cognition, which makes the existence of objective truth possible; and (4) the 'partyness' and 'class character' of cognition are unavoidable facts, and so the results of such cognitive activity are to have a party and class character (Podosetnik 1969: 173-176, 184). However, despite the ability of the human mind to reflect the objective world, the process of reflection itself, due to various sociohistorical (e.g., a 'false' partyness of the subject) or psychophysiological (e.g., neurological disorders of any kind) factors, may lead to a distorted 'subjective image' of the 'objective world' (Podosetnik 1969: 176).

It was from this point of view that Soviet scholars of religion examined mysticism: on their view, this phenomenon turned out to be a result of a rationalization of the 'mystical' knowledge totally deprived of any cognitive value. They saw 'mystical' knowledge as a distorted, 'perverted', and 'fantastic' reflection of objective reality in the human mind caused both by psychopathological and epistemological factors - which could explain apparent similarities between mystical experiences and mystical teachings across religions and cultures - and by cultural, historical and socioeconomic circumstances (for example, cf. Popova 1967: 140; Shakhnovich 1965: 4-10; Portnov and Shakhnovich 1967: 19-20; Ius 1970: 184; Rozhnov 1977: 7-8; Rozhnov and Rozhnova 1978: 46-47).

\section{MYSTICAL 'EXPERIENCE' AND THE SOCIOCULTURAL APPROACH}

This approach made it impossible to discuss the relationship between mystical experience and its interpretation that was and still is an integral part of Western discourse on mysticism and mystical experience. This difference can be further understood if we note that Western discussions of mysticism included a confrontation between two approaches to the study of the 'mystical'. The first approach, essentialism, presupposes the existence of a common core of mystical experiences across different cultural and religious traditions. The second approach, constructivism or contextualism, insists on a pluralistic understanding of religious traditions and on the absolute dependence of the phenomenological contents of religious experiences on their subjects' conceptual structures, 
and it regards the generalized concepts 'mystical experience' and 'mysticism' as empty constructs.

Notably, Soviet scholars of religion tried to avoid using 'mystical experience' and 'religious experience' as scientific categories, viewing them as by-products of Western psychology of religion. It was quite common in this context to refer to Vladimir Lenin, who emphasized the "fuzziness and vagueness of the concept "experience" in the bourgeois philosophy of the $20^{\text {th }}$ century, which was designed to veil the subjective and idealistic character of any given philosophical conception' (Ugrinovich 1985: 134; cf. Ugrinovich 1986: 150-154; Popova 1967: 126; Visnap 1974: 29, 36; Nosovich 1989: 100-104). Soviet scholars inevitably deemed any mystical state of consciousness to be 'a mental disorder', an 'extreme manifestation of religious fanaticism', and so on (cf. Shakhnovich 1965: 10). In the best tradition of the 'medical materialism' of the late $19^{\text {th }}$ and early $20^{\text {th }}$ centuries, religious or mystical ecstasy was likened to epilepsy and alcohol or drug intoxication, and was genetically associated with psychopathologies such as neurosis, hysteria, schizophrenia, paranoia, manic depressive disorder, melancholy, and with masochistic and sexual fantasies, caused by excessive asceticism and 'unnatural mortification of the flesh'. As has already been mentioned, it was this psychophysiological basis, from the Soviet scholars' perspective, that explained the similarity between mystical experiences across religious traditions and cultures (Portnov and Shakhnovich 1967: 34-41; Shakhnovich 1965: 10-14; Platonov 1967: 135-137).

However, these physiological explanations themselves were considered to be an insufficient explanation for mystical ecstasy, because they overlooked entirely the real social and historical roots of mysticism. Furthermore, the 'biologization' of religiousness, which was attributed to Western psychologists of religion, ${ }^{13}$ was, in the opinion of Soviet scholars, fraught with the danger of admitting the 'eternal and ineradicable' nature of religion (Bukina 1966: 124-128; cf. Bukina and Popova 1971: 122-124, 129-130; Shakhnovich 1965: 10; Ius 1970: 127-130, 184; Nemanov, Rozhnova, and Rozhnov 1969: 9-10; Rozhnov 1977: 7; Khrshanovsky 1977: 23-24; Gurevich 1984: 6). Moreover, Soviet scholars held that an emphasis on individual, context-independent mystical experiences

${ }^{13}$ A lot of criticism was directed at works of non-Russian psychologists of the late 19th and early 20th centuries (James H. Leuba, Edwin D. Starbuck, Théodore Flournoy, Théodule-Armand Ribot, and William James, among others), as well as at works of perennialists and members of the so-called anti-psychiatry movement. 
would result in a pluralist interpretation of mysticism, which was regarded as the main obstacle to a 'unified theory of religious experiences' (Bukina 1966: 144; cf. Ugrinovich 1971: 11-12; Ugrinovich 1986: 153154; Gurevich 1989: 229). The belief in the existence of a single objective reality led to a paradoxical situation in Soviet scholarship, as compared to the situation in Western research on mysticism. Soviet scholars of religion criticized both empiricism in research on mysticism and on religion in general, and appeal to the concept of 'pure' or 'contentless' experience, but at the same time they opposed a pluralist understanding of these phenomena. They thus combined doctrinal essentialism with sociocultural determinism, while the Western view was that empiricism traditionally involved a kind of essentialism, while sociocultural interpretations relied on a constructivist epistemology. ${ }^{14}$

Accordingly, Soviet scholars deemed any theory of mysticism and mystical experience that overlooked their 'objective' social and cultural conditioning to be incomplete and one-sided, because the contents of mystical consciousness had to derive from 'specific historical and social relations'. Certain factors might even provoke a mystical 'epidemic' if they were combined with the psychological and epistemological features of individuals (e.g., heightened sensitivity, suggestibility, active imagination, lack of education, etc.). Such factors included the supremacy of reactionary ideology, political and social upheaval, poverty, hunger, and injustice that led to a feeling of insignificance and defencelessness (cf. Shakhnovich 1965: 10-11, 21-27, 50; Portnov and Shakhnovich 1967: 37; Balagushkin 1989: 269-295; Mitrokhin 1989: 7-8). Historical changes of socio-economic formations were, according to Soviet scholars, inevitably accompanied by bursts of mystical moods, which may have had the function of compensating for those changes. ${ }^{15}$ For example, it

${ }^{14}$ In the works of Soviet scholar of religion Yu. A. Kimelev, constructivists and essentialists were called 'ideologists of religion' and 'researchers of mysticism', respectively (cf. Kimelev 1989: 251-252).

15 Perhaps the most interesting project along these lines was an attempt undertaken in 1977 by Soviet researcher Vladimir Khrshanovsky to explain the genesis of mystical experiences and ideas in terms of Leon Festinger's cognitive dissonance theory. Khrshanovsky held that people in modern Western societies were constantly suffering from the state of cognitive dissonance. This dissonance was due to the fact that people in Western societies were not being able to meet their religious needs by means of traditional religiosity, which runs counter to the spirit of scientific knowledge. This inability to meet their religious needs was caused by the social and economic oppression of the capitalist system. In such a situation, 'irrational mysticism' could 'escape the rationalist criticism 
was common to argue that the three particularly significant periods in the history of European mysticism coincided with the end of the Ancient World, the decline of feudalism, and the crisis in the capitalist system (cf. Shakhnovich 1965: 15-27; Smirin 1947; Khrshanovsky 1977).

\section{CONCLUSION}

In conclusion, it should be emphasized that the specifics of Soviet theories of mysticism and mystical experience were determined by the epistemological paradigm of dialectical materialism, in which mysticism and related phenomena were automatically regarded as a 'distorted' reflection of reality. Without anything further to restrict it, the category of mysticism turned into a vast grouping of heterogeneous phenomena, such as traditional religious mysticism, animistic beliefs, shamanism, theosophy, occultism, spiritualism, alchemy, Gnosticism, astrology, and magic. This perspective eventually led to the almost complete exclusion of 'mystical experience' from the categories of Soviet religious studies in general and of psychology of religion in particular. Another consequence of this approach was a situation that was diametrically opposed to the situation found in Western research on mysticism: despite the critique of empiricism, which ignored the 'objective' social and historical roots of the 'mystical', Soviet scholars of religion turned out to be proponents of a rather essentialist approach, which, in its most radical form, held to the phenomenological unity not only of mystical experiences, but also of mystical doctrines. In contrast, their Western counterparts tended to combine the essentialist interpretation of mysticism and mystical experiences with empiricism. All of these features defined Soviet mystical studies, and they continue to determine the general course of interpretations of mysticism and mystical experience in religious studies in contemporary Russia. These features of mystical studies are still in need of a thorough analysis and careful evaluation.

and, at the same time, satisfy the religious needs' of the individual, thus resolving the dissonance (Khrshanovsky 1977: 177-179). Unfortunately, Khrshanovsky's attempt received no further development. 


\section{BIBLIOGRAPHY}

Abaev, N. V. 1983. Chán and the Culture of Mental Activity in Medieval China (Novossibirsk: Nauka) (In Russian)

Abdurashidova, Z. A. 2010. 'Mysticism as a Conceptual Form of Expression of the Activity Nature of the Knowing of God', Gosudarstvo, religiya, tserkov' $v$ Rossii i za rubezhom, 2: 129-135 (In Russian)

Angeles, P. A. 1966. 'Comments on Professor Clark's 1965 Presidential Adress "The Mystical Consciousness", Journal for the Scientific Study of Religion, 5: 290-293

Balagushkin, E. G. 1989. 'Socio-political Activity of Modern Religious and Mystical Cults and Organizations', Voprosy nauchnogo ateizma, 38: 269-295 (In Russian)

Balagushkin, E. G. 2008. 'Analytical Theory of Mysticism', in Evgenii Balagushkin and Aleksei Fokin, eds., Mysticism: Theory and History (Moscow: IFRAN), pp. 14-71 (In Russian)

Belov, A. V. and D. A. Karpov. 1978. Mysticism in the Service of Anti-Communism (Moscow: Znanie) (In Russian)

Bessonova, L. A. 1998. Mysticism as a Cultural Phenomenon (Moscow: unpublished doctoral dissertation) (In Russian)

Bukina, I. N. 1966. Modern Bourgeois Psychology of Religion: Critical Historical and Philosophical Essays (Leningrad: unpublished doctoral dissertation) (In Russian)

Bukina, I. N. and M. A. Popova. 1971. 'The Evolution of Bourgeois Psychology of Religion, Voprosy nauchnogo ateizma, 11: 113-147 (In Russian)

Clark, W. H. 1965. 'The Mystical Consciousness and World Understanding', Presidential Address, Society for the Scientific Study of Religion, 1964. Journal for the Scientific Study of Religion, 4: 152-161

Devina, I. V. 1989. 'Mysticism and Religion', Voprosy nauchnogo ateizma (review of Soviet literature), 39: 252-277 (In Russian)

Eremenko, V. P. 1978. Nonconfessional Mysticism: Its Specificity, Character of Manifestation, and the Ways to Overcome (Dnepropetrovsk: unpublished doctoral dissertation) (In Russian)

Gordienko, N. S. 1981. Mysticism in the Service of Modern Orthodoxy (Moscow: Obshchestvo 'Znanie' RSFSR) (In Russian)

Grigorenko, A. Yu. 1986. The Dream of Reason Produces Monsters: Critical Essays on Mysticism and Irrationalism (Leningrad: Lenizdat) (In Russian)

Gurevich, P. S. 1984. Has Mysticism Revived?: Critical Essays (Moscow: Politizdat) (In Russian)

Gurevich, P. S. 1989. 'Ideological Aspects of the Relationship between Science and Mysticism', Voprosy nauchnogo ateizma, 38: 227-248 (In Russian)

Hollenback, J. B. 1996. Mysticism: Experience, Response, and Empowerment (University Park, Pennsylvania: Pennsylvania State University Press) 
Hood, R. W. 2006. 'The Common Core Thesis in the Study of Mysticism', in Patrick McNamara, ed., Where God and Science Meet: How Brain and Evolutionary Studies Alter Our Understanding of Religion, Vol. 3: The Psychology of Religious Experience (Westport: Praeger Publishers), pp. 119-135

Ius, A. G. 1970. Philosophical Problems of Study of Religious Belief and Religious Feelings (Moscow: unpublished doctoral dissertation) (In Russian)

Inge, W. R. 1918. Christian Mysticism (London: Methuen \& Co. Ltd.)

Inge, W. R. 1947. Mysticism in Religion (London: Hutchinson's University Library)

James, W. 2008. The Varieties of Religious Experience: A Study in Human Nature (Rockville, Maryland: Arc Manor LLC.)

Khalturin, Yu. 2013. 'Esotericism and Worldview of the Russian Freemasonry of the $18^{\text {th }}-19^{\text {th }}$ Centuries: Toward a Conceptualization', State, Religion and Church in Russia and Worldwide, 4(31): 87-112 (In Russian)

Khor'kov, M. L. 2003. Meister Eckhart: Introduction to the Philosophy of the Great Rhenish Mystic (Moscow: Nauka) (In Russian)

Khrshanovsky, V. A. 1977. The Critical Analysis of Modern Nonconfessional Mysticism in the Capitalist Countries (Leningrad: unpublished doctoral dissertation) (In Russian)

Kimelev, Yu. A. 1989. 'Problems of Mysticism in the Bourgeois Philosophical Study of Religion', Voprosy nauchnogo ateizma, 38: 249-268 (In Russian)

Klimovich, A. G. 2003. Religious Mysticism as a Philosophical Problem (Tyumen: unpublished doctoral dissertation) (In Russian)

Kononov, V. I. 1985. Mysticism and Occultism in the Service of the 'Neoconservative wave' Ideologues (Moscow: Znanie) (In Russian)

Krishan, D. 1954. 'Mysticism and the Problem of Intelligibility', The Journal of Religion, 34: 101-105

Lévy-Bruhl, L. 1923. Primitive Mentality, trans. L. A. Clare (London: George Allen \& Unwin LTD; New York: The Macmillan Company)

Mitrokhin, L. N. 1989. 'Mysticism as a Historical and Cultural Phenomenon', Voprosy nauchnogo ateizma, 38: 3-51 (In Russian)

Nasyrov, I. R. 2007. 'On the Essence of the Muslim Mysticism (Sufism)', Religiovedenie, 4: 37-43 (In Russian)

Nemanov, I. N., M. A. Rozhnova, and V. E. Rozhnov. 1969. When the Ghosts Show Claws (Moscow: Gospolitizdat) (In Russian)

Nosovich, V. I. 1989. The Nature, Structure, and Functions of Religious Psychology (Tallin: unpublished doctoral dissertation) (In Russian)

Pakhomov, S. V., ed. 2009. Mystical and Esoteric Movements in Theory and Practice: History, Psychology, Philosophy (St. Petersburg: RHGA) (In Russian)

Pakhomov, S. V., ed. 2010. Mystical and Esoteric Movements in Theory and Practice: The Problems of the Interpretation of Esotericism and Mysticism (St. Petersburg: RHGA) (In Russian) 
Pakhomov, S. V., ed. 2012. Mystical and Esoteric Movements in Theory and Practice: History and Discourse: Historical and Philosophical Aspects of the Study of Esotericism and Mysticism (St. Petersburg: RHGA) (In Russian)

Pakhomov, S. 2013. 'Specific Features of Contemporary Russian Esoteriology', State, Religion and Church in Russia and Worldwide, 4(31):36-65 (In Russian) Panchenko, A. A. 2004. Khlystism and Skoptsism: Folklore and Traditional Culture of Russian Mystical Sects (Moscow: O. G. I.) (In Russian)

Platonov, K. K. 1967. Psychology of Religion: Facts and Thoughts (Moscow: Izdatel'stvo politicheskoi literatury) (In Russian)

Plekhanov, G. V. 1977. On Atheism and Religion in the History of Society and Culture: Selected Works (Moscow: Mysl') (In Russian)

Podosetnik, V. M. 1969. 'Lenin's Reflection Theory and the Problem of the Subject's Activity in the Process of Cognition', in Mark Rozental, ed., Lenin as a Philosopher (Moscow: Gospolitizdat) (In Russian)

Polikarpov, B. C. 1990. Science and Mysticism in the 20 $0^{\text {th }}$ Century (Moscow: Mysl') (In Russian)

Popova, M. A. 1967. Criticism of Modern American Psychology of Religion (Moscow: unpublished doctoral dissertation) (In Russian)

Portnov, A. A. and M. I. Shakhnovich. 1967. Psychosis and Religion (Leningrad: Meditsina) (In Russian)

Pypin, A. N. 1916. Russian Freemasonry in the $18^{\text {th }}$ Century and in the First Quarter of the $19^{\text {th }}$ Century (Petrograd: Izdatel'stvo 'Ogni') (In Russian)

Reutin, M. Yu. 2011. Mystical Theology of Meister Eckhart: The Tradition of Plato's 'Parmenides' in the Late Middle Ages (Moscow: RGGU) (In Russian)

Romanova E. G. 2008. 'The Mystical Space of the Internet', in Evgenii Balagushkin and Aleksei Fokin, eds., Mysticism: Theory and History (Moscow: IFRAN), pp. 179-201 (In Russian)

Rotovsky, A. A. 1989. 'Neomysticism and the Difficulties of Ideological Warfare', Voprosy nauchnogo ateizma, 38: 316-331 (In Russian)

Rozhnov, V. E. 1977. Prophets and Wonderworkers: Essays on Mysticism (Moscow: Politizdat) (In Russian)

Rozhnov, V. and M. Rozhnova. 1978. 'Mysticism Does Not Help', Nauka i religiya, 9: 46-47 (In Russian)

Schleiermacher, F. D. 1821. Über die Religion: Reden an die Gebildeten unter ihren Verächtern (Berlin: G. Reimer)

Shakhmatova, E. 2000. 'Vindication of Mysticism: Russia and Europe in the Mirror of the East', Russia and the West: The Dialogue or Collision of Cultures: The Collection of Articles (Moscow: RIK), pp. 47-75 (In Russian)

Shakhnovich, M. I. 1965. Contemporary Mysticism in the Light of Science (Moscow: Nauka) (In Russian)

Shakhnovich, M. I. 1970. Mysticism on the Stand of Science (Moscow: Znanie) (In Russian) 
Shokhin, V. K. 1994. 'Samkhya-Yoga and the Gnostic Tradition', Voprosy filosofii, 7-8: 188-207 (In Russian)

Smirin, M. M. 1947. Thomas Müntzer's National Reformation and the Great Peasant's War (Moscow; Leningrad: Izdatel'stvo Akademii Nauk SSSR) (In Russian)

Solovyov, V. S. 1988. Collected Works in Two Vols., Vol. 2 (Moscow: Mysl') (In Russian)

Stepanyants, M. T. 2009. The Muslim Mysticism (Moscow: 'Kanon+' ROOI 'Reabilitatsiya') (In Russian)

Tazhurizina, Z. A. 2006. 'Mysticism', in Andrei Zabiyako, Alexander Krasnikov, and Ekaterins Elbakyan, eds., Religious Studies / Encyclopaedic Dictionary (Moscow: Akademicheskii Proekt), p. 642 (In Russian)

Tolstikov, V. A. 2007. The Relationship between Rational and Irrational in Mystical Experience (Belgorod: unpublished doctoral dissertation) (In Russian)

Torchinov, E. A. 1993. Taoism: A Historical and Religious Studies Analysis (St. Petersburg: Andreev i synov'ya) (In Russian)

Torchinov, E. A. 2005. Religions of the World: Experience of the Transcendence: Transpersonal States and Psychotechnique (St. Petersburg: Azbuka-klassika, Peterburgskoe Vostokovedenie) (In Russian)

Ugrinovich, D. M. 1985. Introduction to Religious Studies (Moscow: Mysl') (In Russian)

Ugrinovich, D. M. 1986. Psychology of Religion (Moscow: Politizdat) (In Russian) Ugrinovich, D. M. 1971. 'On the Subject of Psychology of Religion and its Place in the System of Sciences', Voprosy nauchnogo ateizma, 11: 9-28 (In Russian)

Vasil'ev, L. L. 1963. Mysterious Phenomena of the Human Mind (Moscow: Gospolitizdat) (In Russian)

Visnap, N. E. 1974. Psychology of religion in Russia in the second half of XIX early XX century (Leningrad: unpublished doctoral dissertation) (In Russian)

Volkov, S. N. 2004. The Phenomenon of Mysticism: Its Origins and the Modern State in Russia (Saransk: Unpublished doctoral dissertation) (In Russian)

Volkova, A. N. 2002. Phenomenology of Mystical Experience (St. Petersburg: UMTs Komiteta po obrazovaniyu Administratsii SPb) (In Russian)

Yablokov, I. N., ed. 2002. Religious Studies: Study Aid and Minimum Religious Studies Glossary (Moscow: Gardariki) (In Russian)

Yatskevich, O. B. 2004. Philosophical Analysis of Peculiarities of the Spiritual Nature of Mysticism (Kemerovo: unpublished doctoral dissertation) (In Russian)

Zinnbauer, B. J., K. I. Pargament, B. Cole, M. S. Rye, E. M. Butter, T. G. Belavich, et al. 1997. 'Religion and Spirituality: Unfuzzying the Fuzzy', Journal for the Scientific Study of Religion, 36: 549-584 